\title{
Effects of different holding types and times on quality attributes of oil obtained from olives belonging to Akhisar Region, Turkey
}

\section{Pelin Günç Ergönül, Tuba Göldeli}

\author{
Manisa Celal Bayar University, Manisa, Turkey
}

\section{Keywords:}

Olive

Akhisar

Properties

Oxidative

Stability

Quality

\section{Article history:}

Received 18.02.2018

Received in revised

form 23.03.2018

Accepted 29.03.2018

\section{Corresponding author:}

Pelin Günç Ergönül

E-mail:

pelingunc81@

hotmail.com

DOI: $10.24263 / 2304-$

974X-2018-7-1-4

\section{Abstract}

Introduction. In this study, it was aimed to determine the effects of different holding types and times on quality attributes of oil obtained by extraction using Abencor system.

Materials and methods. Edremit and Uslu types of olives which are widely grown in the region of Akhisar, constitute the main material of the study. These two kinds of olives were filled into plastic boxes or nylon sacks. After waiting for $0,7,14,21$ days, oils were extracted by using Abencor system. Free fatty acid, peroxide value, UV absorption values (at 232 and $270 \mathrm{~nm}$ ), the amount of total phenol, refractive index, the amount of total chlorphyll and carotenoid contents, fatty acid composition and color values were determined in olive oil samples. Oxidative stabilities and sensorial properties of olive oils were also examined.

Results and discussion. The results indicated that loss in quality of the samples, especially the Uslu variety, holded in sacks. Total phenol content of olive oils were decreased excessively during the holding time for both types of samples. Although the majority of the chemical parameters fell within the limits established by the Legislation. Chlorophyll and carotenoid contents ranged, respectively from 0.7 to $8.69 \mathrm{mg} / \mathrm{kg}$ and from 0.7 to $3.44 \mathrm{mg} / \mathrm{kg}$ for Edremit olive oil and from 0.93 to 2.17 $\mathrm{mg} / \mathrm{kg}$ and from 0.96 to $1.49 \mathrm{mg} / \mathrm{kg}$. Oleic (C18:1), linoleic (C18:2), palmitic (C16:0) and stearic (C18:0) acids found as predominant fatty acids in all samples. Oil samples obtained from Edremit variety on the first day of holding and the 7th day of the holding period in sack were classified as extra virgin olive oil. Also oil obtained from Uslu variety on the first day of the holding period showed the caracteristics of extra virgin olive oil according to the sensorial properties. Whereas other samples were classified as virgin olive oil. The initial Induction Period (IP) of Edremit and Uslu olive oils were 3.9 and $3.8 \mathrm{~h}$. For Uslu variety, it was observed a decrease during holding period at each holding types until 21 th day. For Edremit variety, it was not observed a significant decrease during holding period.

Conclusion. According to the results, the chemical parameters analysed in the different samples are within the limits established by the legislation, but vary during the holding period and according to the variety. 


\section{Introduction}

Olive is a typical plant of Mediterranean countries grown in Aegean, Marmara, Mediterranean and South East Anatolian regions of Turkey. Spain is leading the field in olive oil production and olive growing. Italy, Greece and Turkey follow Spain in olive oil production, respectively. The share of our country in world olive oil production is $5,8 \%$. With mentioned the positive effects of olive oil on health by the experts, its consumption gradually increase in countries with high level of income. Greece continues to lead the ranking with $12.8 \mathrm{~kg}$ per capita per year. It is followed by Spain $(11.3 \mathrm{~kg})$, Italy $(11.3 \mathrm{~kg})$, Portugal (10.5 kg), Cyprus (5.5 kg), Luxemburg (3.2 kg), Malta (3 kg), France (1.7 kg) and Turkey $(1.4 \mathrm{~kg})$ [IOOC, 2015]. Period among the planting of olive tree and serving the olive and olive oil to consumer includes extensive processes such as cultural applications like using appropriate variety, planting and pruning and the other processes like harvesting, transportation, pressing and holding. These processes directly affect both olive and olive oil quality and the amount of product which might be obtained in the future.

In this study, it was aimed to determine the effects of different holding types and times on quality attribute of oil obtained after the pressing. Edremit and Uslu type olive cultivars which are widely grown in the region of Akhisar, Turkey that constitute the main material of the study are harvested in 2012-2013 crop season. Their maturation index was indicated. Then these two kinds of olives filled into boxes and nylon sacks and after waiting for 0,7 , 14, 21 days, oils were extracted by using Abencor system. Free fatty acid, peroxide value, UV absorption values (232 and 270), the amount of total phenol, refractive index, color values, the amount of total chlorophyll and carotenoid contents, fatty acid composition were determined as analytical criteria in olive oil samples. The results of the analyses were compared with the criteria given in the Communication for Edible Olive Oil and Olive Pomace of Turkish Food Codex and International Olive Council Legislation and scientific researches [Anon 2014; IOC 2015]. In addition, sensory properties and oxidative stability were evaluated as quality criteria. Up to our knowledge there are rather limited studies about determination the effects of holding times and types on olive oil quality so it's invented that these results elucidate to researchers.

\section{Materials and Methods}

\section{Materials}

Edremit and Uslu varieties of olive which are widely cultivated in Akhisar Region of Manisa/Turkey were used. Olives were manually harvested randomly as $10 \mathrm{~kg}$ for each variety at 2012 and 2013 harvest season. Harvested samples for each variety were put into plastic boxes $(53 \times 37 \times 31 \mathrm{~cm})$ and nylon sacks $(60 \times 90 \mathrm{~cm})$ and were kept inside of them for 0, 7, 14 and 21 days (Figure 1 and Figure 2). Samples were randomly taken from the plastic boxes or nylon sacks for each analysis period. Then they were crushed by Abencor system at Institute of Olive Researches, Bornova/Izmir. They were filtered and filled into the darkbottles and kept at $4^{\circ} \mathrm{C}$ until being analyzed. Each of the analyses were repeated three times for each smple. 


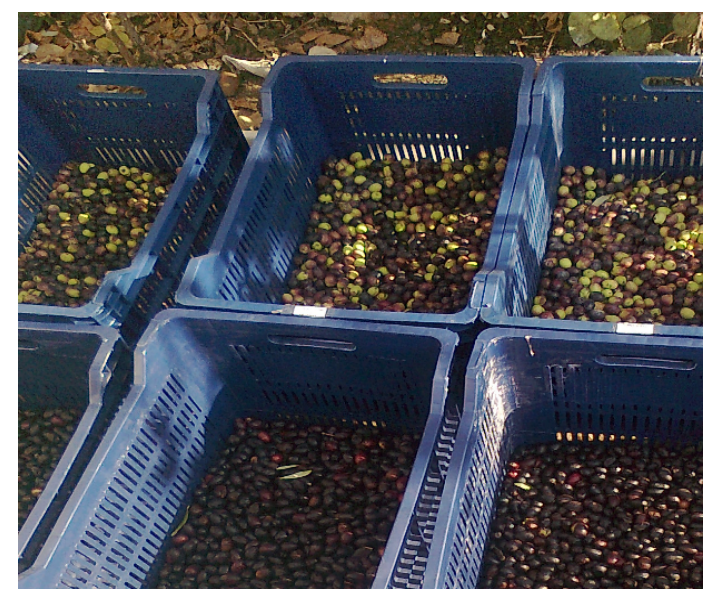

Figure 1. Olive samples holded in plastic boxes

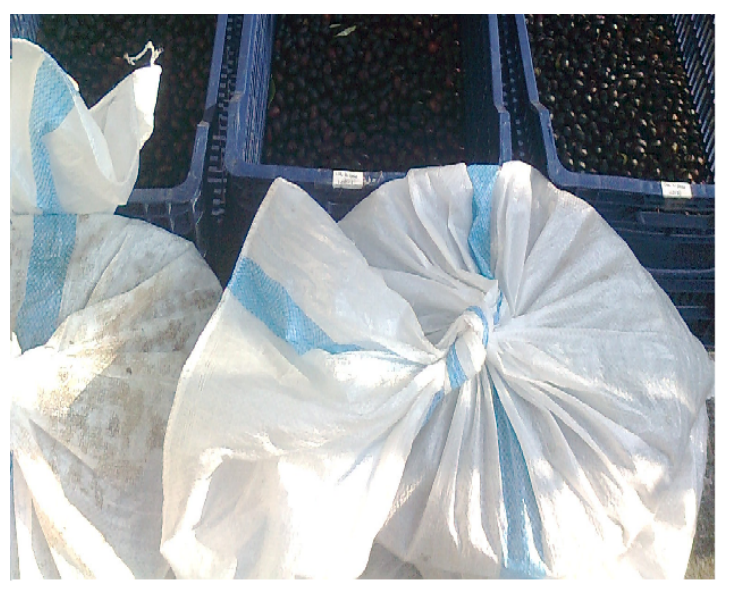

Figure 2. Olive samples holded in nylon sacks

\section{Maturation index}

The MI of olive fruits was determined according to the method given in by Vinha et al. [2005]. MI was calculated after visual colour inspection over a hundred randomly chosen olives, according to the following formula: $\mathrm{MI}=(\mathrm{a} \times \mathrm{x})+(\mathrm{b} \times 1)+(\mathrm{c} \times 2)+(\mathrm{d} \times 3)+(\mathrm{e} \times 4)+(\mathrm{f} \times$ $5)+(g \times 6)+(h \times 7) / 100$. Where $a, b$, etc. are the number of olives in each of the seven colour classes from dark green to dark black.

\section{Olive oil extraction by Abencor system}

Oil was extracted using an Abencor laboratory mill (Polat Machinery Inc.), simulating commercial oil extraction systems. Extraction process consisted of the following steps: fruit 
crushing and malaxation for $60 \mathrm{~min}$ at $35 \pm 1{ }^{\circ} \mathrm{C}$, two rounds of centrifugation, $60 \mathrm{~s}$ each at $3000 \mathrm{rpm}$, with $100 \mathrm{~mL}$ water added between rounds. After centrifugation, oils were decanted, filtered, transferred into amber glass bottles and holded at $4{ }^{\circ} \mathrm{C}$ until analysed.

\section{Determination of physical characteristics}

Color valuesof the olive oil samples were determined in terms of $\mathrm{L}^{*}, \mathrm{a}^{*}$, and $\mathrm{b}^{*}$ criteria using Lovibond PFX880-Tintometer [AOCS 1993a]. The optical path lenght of the glass cell was 1" for extra virgin olive oil. The refractive index values of the samples were carried out using method of Turkish Standard 4960 EN ISO 6320 by Abbe Refractometer at $20^{\circ} \mathrm{C}$ [Anon, 2010].

\section{Determination of quality criteria}

The samples were analyzed after each holding times and types. Acidity (\% as oleic acid) and peroxide value (meq $\mathrm{O}_{2} / \mathrm{kg}$ ) of the virgin olive oil samples were carried out according to the method reported by AOCS [1993b]. and Salvador et al. [2000]. UV specific extinctions of $K 232$ and $K 270$ were determined by Anon [2014]. Chlorophylls and carotenoids were determined colorimetrically following the method [Morello et al. 2004; Beltran et al. 2005]. The maximum absorption at $670 \mathrm{~nm}$ is related to the chlorophyll fraction and at $470 \mathrm{~nm}$ is related to carotenoid fraction.

\section{Total phenol content}

Total polyphenol content was analyzed as described [Gutfinger, 1981]. The phenolic compounds were isolated from a solution of oil in hexane by extraction with a water/ methanol mixture $(60: 40, \mathrm{v} / \mathrm{v})$. The Folin-Ciocalteau reagent was added to a suitable aliquot of the combined extracts, and the absorption of the solution was measured at 725 $\mathrm{nm}$. The results were evaluated in terms of gallic acid as $\mathrm{mg} \mathrm{GA} / \mathrm{kg}$ oil.

\section{Fatty acid composition}

Fatty acid compositions of the oil samples were determined by GC [AOCS, 1997]. Methyl esters were prepared by vigorous shaking of a solution of each olive oil sample in n-hexane $(0.2 \mathrm{~g}$ in $5 \mathrm{~mL})$ with $0.5 \mathrm{~mL} 2 \mathrm{~N}$ methanolic potassium hydroxide solution. Chromatographic analysis was performed on a Agilent Technologies 6890N Gas Chromatograph (Hewlett-Packard Company, Wilmington, DE, USA), equipped with a capillary column (Agilent 122-2362: $60 \mathrm{~m}$ x $0.25 \mathrm{~mm}$ x $0.25 \mu \mathrm{m}$ ), an injector split-splitless and a FID detector. The carrier gas was nitrogen, with a flow rate of $25 \mathrm{ml} / \mathrm{mn}$. Initial oven temperature was $170^{\circ} \mathrm{C}$, raised at $2^{\circ} \mathrm{C} / \mathrm{min}$ to $210^{\circ} \mathrm{C}$ and hold for $15 \mathrm{~min}$. The temperatures of the injector and the detector were held at $250{ }^{\circ} \mathrm{C}$. Fatty acids were identified by comparing retention times with those of standard compounds.

\section{Measurement of oxidative stability}

An automated Metrohm Rancimat apparatus model 743 (Metrohm, Switzerland) capable of operating over a temperature range of $50-200^{\circ} \mathrm{C}$ was used for induction period determination of oil samples. Fourteen oil samples were analyzed in the equipment at the same time. For oxidative stability measurement, each oil sample $(3.0 \pm 0.1 \mathrm{~g})$ was weighted 
into the reaction vessel glassware. The conductimetry cells were filled with deionized water up to $90 \mathrm{ml}$. Air was flown through the heated oil at different rates, depending on the temperature. The flow rate of air was $20 \mathrm{l} / \mathrm{h}$ used for $120^{\circ} \mathrm{C}$. Although this equipment (Model $743 \mathrm{Metrohm}$ ) presents a cleaner system of procedure, the glassware was rigorously cleaned between each run to avoid any contamination that would catalyze the peroxidation [Anwar et al. 2003; Mateos et al. 2006].

\section{Sensory profile analysis}

Sensory analysis was carried out by a panel of 10 selected trained judges of the Olive Oil Research Institute, Эzmir, Turkey, coordinated by a panel head [IOOC, 2010]. The sensory sessions were conducted in a sensory room equipped with 10 boots. Panellists evaluated olive oil samples as their negative and positive properties on a scale from 0 to 5 .

\section{Statistical Analysis}

The data was analyzed utilizing the PROC MIXED procedure of SAS [SAS, 2000]. To find the treatment combination, means including all treatment combinations (holding time, holding types) for each olive variety were generated using the PROC MIXED procedure and these were compared to a control.

\section{Results and Discussion}

\section{Physical caracteristics of olive oil samples}

According to the different holding types and times, physical caracteristics of olive oils obtained from Edremit and Uslu varieties which were harvested at the maturation index of 3.75 and 4.5 respectively, are given in Table 1 and 2.

$\mathrm{L}^{*}, \mathrm{a}^{*}$ and $\mathrm{b}^{*}$ values of olive oils were ranged between 19.9-85.81, 2.53-12.64 and 30.33-92.8, respectively. After holding period of the olive samples, $L^{*}, a^{*}$ and $b^{*}$ values of the olive oils increased at both type (Table 1-2). As regards to the statistical results, the interaction of holding types and times was found significantly important for $\mathrm{L}^{*}, \mathrm{a}^{*}$ and $\mathrm{b}^{*}$ values at Edremit variety while it was found significantly important only for $L^{*}$ and $b^{*}$ values at Uslu variety $(p<0,0001)$. The holding conditions and holding times of olives after harvest, cultivar, soil, climate conditions, degree of ripeness and irrigation can affect color, smell, taste and stability of oils [Kritsakis, 1998]. So, there are differences between initial and subsequent color values of olive oil samples.

One of the physical purity criteria is refractive index values for natural olive oils. Refractive index values of the samples wereamong 1,4696-1,4708. When compared with initial values, there were a slight decrease for each variety due to the holding types and times (Table 1-2). 
Table 1

Least squares means of holding times and holding types on color values $\left(\mathrm{L}, \mathrm{a}^{*}, \mathrm{~b}^{*}\right)$ and refractive index (RI) value for Edremit variety olive oil ${ }^{\text {a }}$

\begin{tabular}{|c|c|c|c|c|}
\hline Source of variation & $\mathbf{L}$ & $a^{*}$ & $\mathbf{b}^{*}$ & $\begin{array}{l}\mathrm{RI}(\mathrm{nD} \\
\left.20^{\circ} \mathrm{C}\right)\end{array}$ \\
\hline \multicolumn{5}{|l|}{ Holding times, week } \\
\hline 0 & 85,79 & 12,09 & 80,09 & $1,4704 a$ \\
\hline 7 & 82,49 & 6,56 & 50,02 & $1,4702 b$ \\
\hline 14 & 37,49 & 5,2 & 50,73 & $1,4698 \mathrm{c}$ \\
\hline 21 & 45,53 & 6,07 & 60,81 & $1,4697 \mathrm{c}$ \\
\hline P-value & $<0,001$ & $<0,0001$ & $<0,0001$ & 0,0002 \\
\hline \multicolumn{5}{|l|}{ holding types } \\
\hline box & 66,33 & 9,44 & 76,21 & 1,4699 \\
\hline sack & 59,32 & 5,52 & 44,61 & 1,47 \\
\hline P-value & $<0,0001$ & $<0,0001$ & $<0,0001$ & 0,24 \\
\hline \multicolumn{5}{|l|}{$\begin{array}{l}\text { holding timesxholding } \\
\text { types }\end{array}$} \\
\hline $0 / \mathrm{b}$ & $85,77 \mathrm{f}$ & $12,12 \mathrm{~g}$ & $80,07 \mathrm{~d}$ & 1,4704 \\
\hline $0 / \mathrm{s}$ & $85,81 \mathrm{f}$ & $12,06 \mathrm{~g}$ & $80,1 d$ & 1,4703 \\
\hline $7 / \mathrm{b}$ & $80,86 \mathrm{e}$ & $11,61 \mathrm{f}$ & $92,8 \mathrm{e}$ & 1,47 \\
\hline $7 / \mathrm{s}$ & $84,12 f$ & $1,52 \mathrm{a}$ & $71,24 c$ & 1,4704 \\
\hline $14 / \mathrm{b}$ & $55,09 \mathrm{~d}$ & $7,87 \mathrm{e}$ & $71,13 c$ & 1,4698 \\
\hline $14 / \mathrm{s}$ & $19,9 \mathrm{a}$ & $2,53 \mathrm{~b}$ & $30,33 a$ & 1,4698 \\
\hline $21 / b$ & $43,62 b$ & $6,16 \mathrm{~d}$ & $60,84 b$ & 1,4696 \\
\hline $21 / \mathrm{s}$ & $47,44 \mathrm{c}$ & $5,98 \mathrm{c}$ & $60,77 \mathrm{~b}$ & 1,4697 \\
\hline P-value & $<0,0001$ & $<0,0001$ & $<0,0001$ & 0,06 \\
\hline
\end{tabular}

Within columns, means with different letters differ $(P<0.05)$.

${ }^{a}$ Letters were not assigned to main effect lsmeans when interaction was significant 
Table 2

Least squares means of holding times and holding types on color values $\left(\mathrm{L}, \mathrm{a}^{*}, \mathrm{~b}^{*}\right)$ and refractive index (RI) value for Uslu variety olive oil ${ }^{\text {a }}$

\begin{tabular}{|c|c|c|c|c|}
\hline Source of variation & $\mathbf{L}$ & $\mathbf{a}^{*}$ & $\mathbf{b}^{*}$ & $\begin{array}{c}\mathbf{R I}(\mathbf{n D} \\
\mathbf{2 0}\end{array}$ \\
\hline Holding times, week & & & & \\
\hline 0 & 85,29 & $12,6 \mathrm{a}$ & 82,19 & 1,4705 \\
\hline 7 & 77,13 & $10,19 \mathrm{~b}$ & 73,63 & 1,4707 \\
\hline 14 & 80,19 & $10,02 \mathrm{~b}$ & 74,81 & 1,4703 \\
\hline 21 & 80,54 & $10,26 \mathrm{~b}$ & 74,68 & 1,4701 \\
\hline$P$-value & 0,0006 & 0,0004 & $<0,0001$ & 0,11 \\
\hline Holding types & & & & \\
\hline box & 83,24 & 10,91 & 78,22 & 1,4704 \\
\hline sack & 78,33 & 10,63 & 74,43 & 1,4703 \\
\hline P-value & 0,0001 & 0,16 & 0,0001 & 0,0002 \\
\hline Holding timesxholding & & & & \\
\hline types & & & & \\
\hline $0 / \mathrm{b}$ & $85,35 \mathrm{e}$ & 12,64 & $82,2 \mathrm{f}$ & $1,4706 \mathrm{~d}$ \\
\hline $0 / \mathrm{s}$ & $85,22 \mathrm{e}$ & 12,56 & $82,17 \mathrm{f}$ & $1,4704 \mathrm{c}$ \\
\hline $7 / \mathrm{b}$ & $84,4 \mathrm{e}$ & 10,72 & $74,65 \mathrm{c}$ & $1,4706 \mathrm{~d}$ \\
\hline $7 / \mathrm{s}$ & $69,86 \mathrm{a}$ & 9,67 & $72,61 \mathrm{~b}$ & $1,4708 \mathrm{e}$ \\
\hline $14 / \mathrm{b}$ & $83,64 \mathrm{de}$ & 10,02 & $78,95 \mathrm{e}$ & $1,4702 \mathrm{~b}$ \\
\hline $14 / \mathrm{s}$ & $76,73 \mathrm{~b}$ & 10,03 & $70,68 \mathrm{a}$ & $1,4704 \mathrm{c}$ \\
\hline $21 / \mathrm{b}$ & $79,55 \mathrm{c}$ & 10,26 & $77,1 \mathrm{~d}$ & $1,4704 \mathrm{c}$ \\
\hline $21 / \mathrm{s}$ & $81,53 \mathrm{~cd}$ & 10,26 & $72,25 \mathrm{ab}$ & $1,4698 \mathrm{a}$ \\
\hline P-value & 0,0001 & 0,15 & 0,003 & 0,001 \\
\hline & & & & \\
\hline
\end{tabular}

Within columns, means with different letters differ $(P<0.05)$.

${ }^{a}$ Letters were not assigned to main effect lsmeans when interaction was significant

\section{Quality criteria of olive oil samples}

According to the quality indices (free fatty acids, peroxide value and UV absorption parameters, K232 and K270), all samples were in line with the limit values for EVOO, OO and RFOO set by the Turkish Food Codex on Olive Oils and Olive Pomace Oils [Anon, 2014].

As seen in Table 3 and Table 4, FFA of Edremit and Uslu type olive oils increased constantly during holding time. In Edremit variety, FFA increased to $2.7 \%$ from $0.62 \%$ and for Uslu variety it reached upto $1.33 \%$ from $0.25 \%$ at the end of holding period in sacks. Regarding the influence of holding conditions, interaction of holding types and 
holding times affect FFA content of Edremit olive oil variety $(p<0.0001)$ whereas in Uslu olive oil variety only holding times affect FFA content $(p<0.0001)$.It is thought that the reason of the high free fatty acidity of the oil was arised from the mechanical injury of the olives during harvest and the harms occurred during 21-days holding period.

Table 3

Least squares means of holding times and holding types on some analytical criteria and total phenol content for Edremit variety olive oil ${ }^{\text {a }}$

\begin{tabular}{|c|c|c|c|c|c|c|c|}
\hline $\begin{array}{l}\text { Source of } \\
\text { variation }\end{array}$ & $\begin{array}{c}\text { FFA } \\
\text { (\% as } \\
\text { oleic acid })\end{array}$ & $\begin{array}{c}\mathrm{PV} \\
\left(\mathrm{meqO}_{2} / \mathbf{k g}\right)\end{array}$ & $\begin{array}{c}\mathrm{K} 232 \\
\left(\mathrm{E}^{\% 1} \mathbf{1} \mathrm{cm}\right)\end{array}$ & $\begin{array}{c}\mathrm{K} 270 \\
\left(\mathbf{E}^{\% 1} \mathbf{1 c m}\right)\end{array}$ & $\begin{array}{c}\text { Total } \\
\text { chlorophyll } \\
\text { (mg/kg) }\end{array}$ & $\begin{array}{c}\text { Total } \\
\text { carotenoid } \\
(\mathrm{mg} / \mathrm{kg})\end{array}$ & $\begin{array}{c}\text { Total } \\
\text { phenol } \\
\text { (mg/kg GA) }\end{array}$ \\
\hline \multicolumn{8}{|l|}{$\begin{array}{c}\text { Holding } \\
\text { times, week }\end{array}$} \\
\hline 0 & 0,62 & 4,88 & 1,69 & $0,06 \mathrm{a}$ & 0,61 & 0,67 & 251,43 \\
\hline 7 & 0,74 & 4,94 & 1,3 & $0,06 \mathrm{a}$ & 6,59 & 2,77 & 87,28 \\
\hline 14 & 1,6 & 3,4 & 1,7 & $0,18 \mathrm{~b}$ & 4,37 & 2,22 & 62,77 \\
\hline 21 & 2,05 & 3,81 & 1,85 & $0,15 \mathrm{c}$ & 4,21 & 2,25 & 44,27 \\
\hline $\mathrm{P}$-value & $<0,0001$ & $<0,0001$ & 0,16 & $<0,0001$ & $<0,0001$ & $<0,0001$ & $<0,0001$ \\
\hline \multicolumn{8}{|l|}{$\begin{array}{c}\text { Holding } \\
\text { types }\end{array}$} \\
\hline box & 1,06 & 3,98 & 1,48 & $0,1 \mathrm{a}$ & 3,48 & 1,85 & 113,22 \\
\hline sack & 1,44 & 4,54 & 1,78 & $0,12 b$ & 4,4 & 2,1 & 109,64 \\
\hline P-value & $<0,0001$ & 0,0007 & 0,13 & 0,03 & 0,001 & 0,015 & 0,21 \\
\hline \multicolumn{8}{|l|}{$\begin{array}{c}\text { Holding } \\
\text { timesxholding } \\
\text { types }\end{array}$} \\
\hline $0 / \mathrm{b}$ & $0,61 \mathrm{a}$ & $4,83 \mathrm{a}$ & 1,68 & 0,06 & $0,7 \mathrm{a}$ & $0,7 \mathrm{a}$ & $235,03 f$ \\
\hline $0 / \mathrm{s}$ & $0,62 \mathrm{a}$ & $4,93 \mathrm{a}$ & 1,7 & 0,06 & $0,52 \mathrm{a}$ & $0,64 \mathrm{a}$ & $267,83 \mathrm{~g}$ \\
\hline $7 / b$ & $0,75 \mathrm{c}$ & $4,9 \mathrm{a}$ & 0,9 & 0,41 & $4,5 \mathrm{~b}$ & $2,11 b$ & $100,13 \mathrm{e}$ \\
\hline $7 / \mathrm{s}$ & $0,73 b$ & $4,99 a$ & 1,7 & 0,82 & $8,69 c$ & $3,44 \mathrm{c}$ & $74,39 \mathrm{~d}$ \\
\hline $14 / b$ & $1,47 \mathrm{e}$ & $3,11 \mathrm{~d}$ & 1,7 & 0,18 & $4,43 b$ & $2,34 b$ & $64,48 \mathrm{c}$ \\
\hline $14 / \mathrm{s}$ & $1,73 \mathrm{f}$ & $3,69 \mathrm{c}$ & 1,7 & 0,18 & $4,3 b$ & $2,1 b$ & $61,06 \mathrm{bc}$ \\
\hline $21 / b$ & $1,41 d$ & $3,08 \mathrm{~d}$ & 1,67 & 0,13 & $4,31 \mathrm{~b}$ & $2,28 b$ & $53,26 \mathrm{~b}$ \\
\hline $21 / \mathrm{s}$ & $2,7 \mathrm{~g}$ & $4,55 b$ & 2,03 & 0,17 & $4,1 b$ & $2,22 b$ & $35,28 \mathrm{a}$ \\
\hline P-value & $<0,0001$ & 0,0034 & 0,33 & 0,18 & 0,001 & 0,0005 & 0,001 \\
\hline
\end{tabular}

Within columns, means with different letters differ $(P<0.05)$.

${ }^{a}$ Letters were not assigned to main effect lsmeans when interaction was significant FFA: Free fatty acid, PV: Peroxide value

It is thought that free fatty acid values of the sample increased due to the activity of lipolytic enzymes in the olive fruit. The activity of this enzyme is influenced from fruit quality, climate conditions, maintenance requirements olives and process conditions [Mateos et al. 2006]. 
The effect of holding time and container type on quality of extra virgin olive oil have reported by Mendez and Falquй [2007]. According to their findings, the acidity of olive oil samples increased to $0.38 \%$ from $0.25 \%$ at the end of 6 -month holding period in plastic containers. It is thought that the differences among the results of the researches with literature data depend to a number of factors as olive harvest time, applied technology, preservation and holding conditions of olives.

Table 4

Least squares means of holding times and holding types on some analytical criteria and total phenol content for Uslu variety olive oil ${ }^{\mathrm{a}}$

\begin{tabular}{|c|c|c|c|c|c|c|c|}
\hline $\begin{array}{l}\text { Source of } \\
\text { variation }\end{array}$ & $\begin{array}{c}\text { FFA } \\
\text { (\% as } \\
\text { oleic acid) }\end{array}$ & $\begin{array}{c}\mathrm{PV} \\
\left(\mathrm{meqO}_{2} / \mathrm{kg}\right)\end{array}$ & $\begin{array}{c}\mathrm{K} 232 \\
\left(\mathrm{E}^{\% 1} 1 \mathrm{~cm}\right)\end{array}$ & $\begin{array}{c}\mathbf{K 2 7 0} \\
\left(\mathbf{E}^{\% 1} \mathbf{1} \mathbf{c m}\right)\end{array}$ & $\begin{array}{c}\text { Total } \\
\text { chlorophyll } \\
\text { (mg/kg) }\end{array}$ & $\begin{array}{c}\text { Total } \\
\text { carotenoid } \\
(\mathrm{mg} / \mathrm{kg})\end{array}$ & $\begin{array}{c}\text { Total } \\
\text { phenol } \\
(\mathrm{mg} / \mathrm{kg} \mathrm{GA})\end{array}$ \\
\hline \multicolumn{8}{|l|}{$\begin{array}{c}\text { Holding } \\
\text { times, } \\
\text { week } \\
\end{array}$} \\
\hline 0 & $0,25 \mathrm{a}$ & $6,09 \mathrm{c}$ & 2,06 & $0,13 \mathrm{a}$ & $1,04 \mathrm{a}$ & 1 & $174,8 \mathrm{a}$ \\
\hline 7 & $0,47 b$ & $9,08 \mathrm{a}$ & 2,27 & $0,14 \mathrm{a}$ & $1,97 \mathrm{~b}$ & 1,22 & $69,82 b$ \\
\hline 14 & $1,11 \mathrm{c}$ & $8,28 \mathrm{ab}$ & 1,9 & $0,17 \mathrm{ab}$ & $1,58 \mathrm{ab}$ & 1,02 & $59,37 \mathrm{c}$ \\
\hline 21 & $1,31 \mathrm{~d}$ & $8 \mathrm{~b}$ & 2,62 & $0,23 b$ & $2,1 b$ & 1,37 & $20,22 \mathrm{~d}$ \\
\hline P-value & $<0,0001$ & 0,0015 & 0,12 & 0,04 & 0,03 & 0,007 & $<0,0001$ \\
\hline \multicolumn{8}{|l|}{$\begin{array}{c}\text { Holding } \\
\text { types }\end{array}$} \\
\hline box & 0,78 & $8,19 b$ & 2,38 & 0,17 & 1,54 & 1,02 & 81,74 \\
\hline sack & 0,79 & $7,53 \mathrm{a}$ & 2,05 & 0,16 & 1,8 & 1,29 & 80,37 \\
\hline P-value & 0,46 & 0,04 & 0,15 & 0,48 & 0,18 & 0,003 & 0,64 \\
\hline \multicolumn{8}{|l|}{$\begin{array}{l}\text { Holding } \\
\text { times- } \\
\text { xholding } \\
\text { types }\end{array}$} \\
\hline $0 / b$ & 0,28 & 6,39 & 2,1 & 0,13 & 0,93 & $0,96 \mathrm{~b}$ & 177,33 \\
\hline $0 / \mathrm{s}$ & 0,22 & 5,79 & 2,02 & 0,12 & 1,14 & $1,04 b$ & 172,26 \\
\hline $7 / b$ & 0,48 & 9,49 & 2,37 & 0,15 & 1,76 & $1,13 b c$ & 71,48 \\
\hline $7 / \mathrm{s}$ & 0,47 & 8,68 & 2,18 & 0,14 & 2,17 & $1,3 \mathrm{~cd}$ & 68,16 \\
\hline $14 / \mathrm{b}$ & 1,09 & 8,66 & 2,37 & 0,2 & 1,41 & $0,72 \mathrm{a}$ & 60,87 \\
\hline $14 / \mathrm{s}$ & 1,14 & 7,9 & 1,42 & 0,14 & 1,76 & $1,33 \mathrm{~cd}$ & 57,88 \\
\hline $21 / \mathrm{b}$ & 1,28 & 8,24 & 2,67 & 0,22 & 2,1 & $1,26 \mathrm{c}$ & 17,26 \\
\hline $21 / \mathrm{s}$ & 1,33 & 7,76 & 2,57 & 0,24 & 2,14 & $1,49 d$ & 23,18 \\
\hline $\mathrm{P}$-value & 0,43 & 0,95 & 0,36 & 0,56 & 0,89 & 0,05 & 0,5 \\
\hline
\end{tabular}

Within columns, means with different letters differ $(P<0.05)$.

${ }^{a}$ Letters were not assigned to main effect lsmeans when interaction was significant 
The peroxide value underwent a significant increase up to the 7th day of holding for both variety, then slowly decreased up to the 21th day in box and sack, probably due to the fact that the newly formed oxidation products were further converted to secondary ones (Table 3-4). But nevertheless, they did not exceed the legal limit of $\leq 20 \mathrm{meqO}_{2} / \mathrm{kg}$ for extra virgin olive oil set by the Anon [2014] and IOC [2015]. According to the statistical results, the interaction of holding types and holding times was found important for Edremit olive oil variety ( $<<0.05$, Table 3$)$, whereas for Uslu olive oil variety, the effect of holding times and holding types were found significantly important $(p<0.05$, Table 4$)$. The peroxide value of Edremit and Uslu type olive oils from different regions and different harvest period have identified. Their peroxide value was changed between 3,01-8,05 meq $\mathrm{O}_{2} / \mathrm{kg}$ and 4,52-8,16 meq $\mathrm{O}_{2} / \mathrm{kg}$, respectively [Yavuz, 2008]. It was observed that these values are similar to the values in our study. It is known that oxygen in the aircausesa rise in peroxide value. Heat and light accelerate these oxidative chemical reactions. Therefore, olives and olive oils should not be exposed to the oxygen for a long time and should be kept in dark places at $10-15{ }^{\circ} \mathrm{C}$ [Allalout et al. 2009].

The initial values of the coefficients K232 and K270 are between 1.68 and 0.06 for Edremit variety and 2.12 and 0.12 for Uslu variety, within the limits permitted by the International Olive Council Legislation [IOC, 2015]. In Table 3 and 4, it can be seen that the effect of different holding times and holding types did not significantly affect the changes in K232 value of both type( $(p>0.05)$. But it was found that holding types and holding times had separately significant importance on the changes in K270 value of Edremit olive oil, whereas only the effect of holding times on K270 value was found significantly important for Uslu olive oil $(\mathrm{p}<0.05)$. K270 value of Uslu olive oil was slightly exceeded the legal limit of $\leq 2.60$ for virgin olive oil as required by IOC at 21th day of holding [IOC, 2015] (Table 4). This occur due to the increase in the number of compounds resulting from the degradation of the hydroperoxides, which is confirmed by an increase of K270 value [Yavuz, 2008].

The natural pigments contents of the oils are important for the quality parameters because they correlate with colour and play a key role as a factor of sensorial acceptability among consumers. Virgin olive oil has a color changing among green-yellow to gold, depending on the variety and the stage of maturity [Salvador et al. 2000]. They undergo during fruit ripening and oil holding so they could be considered as a product freshness indicator [Allalout et al. 2009]. As shown in Table 3 and Table 4, Chlorophyll and carotenoid contents ranged, respectively from 0.7 to $8.69 \mathrm{mg} / \mathrm{kg}$ and from 0.7 to $3.44 \mathrm{mg} / \mathrm{kg}$ for Edremit olive oil and from 0.93 to $2.17 \mathrm{mg} / \mathrm{kg}$ and from 0.96 to $1.49 \mathrm{mg} / \mathrm{kg}$.

These results are in agreement with the findings of which reported that the chlorophylls and carotenoids contents ranged, respectively from 0.05 to $1.52 \mathrm{mg} / \mathrm{kg}$ and $2.03 \mathrm{mg} / \mathrm{kg}$ for Moroccan cultivars [Tanouti et al. 2011]. It should be noted that the values found for the two pigments were low. This can be attributed to the geographical origin, olive cultivar, fruit ripeness, soil and climatic condition and the processing procedures [Psomiadou and Tsimidou, 2001]. Generally, oils obtained in irrigation regime had higher levels of chlorophyll pigments that non-irrigated one. However, the content of carotenoids was less affected by water supply [Baccouri et al. 2008]. Chlorophyll and carotenoid contents of Edremit olive oils have been identified as $0.95-6.73 \mathrm{mg} / \mathrm{kg}$ and $1.51-5.13 \mathrm{mg} / \mathrm{kg}$, respectively. They reported that their contents decreased as maturation index increased [Yorulmaz et al. 2013].

The effect of interaction of the type of holding types and holding times significantly affected the changes in chlorophyll and carotenoid contents of Edremit variety $(\mathrm{p}<0.001$, Table 3), whereas for Uslu variety while the interaction of holding types and holding times 
affected the carotenoid content $(p<0.05$, Table 4). For chlorophyll content, only the effect of holding times was found statistically important $(\mathrm{p}<0.05$, Table 4$)$.

\section{Total Phenol content of olive oil samples}

The amount of total phenolic compounds in virgin olive oil is an important factor when evaluating its quality, given that the natural phenols improve its resistance to oxidation, and to certain extent, are responsible for its bitter taste [Baccouri et al. 2008]. The concentration of total phenols ranged between $35.28-267.83 \mathrm{mg} / \mathrm{kg}$ and $17.26-177.33 \mathrm{mg} / \mathrm{kg}$ for Edremit and Uslu olive oil varieties, respectively (Table 3-4). The higher concentrations of total phenol were found at the beginning of holding for both types. Then total phenols underwent a decrease during holding period. The literature reports that their decrease is due to the decomposition process and the oxidative activity of these compounds [Morello et al. 2004]. The most significant decrease of total phenol content occurred during holding in plastic boxes for both types.

Generally, total phenol content of olive oils was lower according to the literature reports. The characteristics of olive and olive oils during ripening have been examined and they found total phenol content between 550.33-810.98 $\mathrm{mg} / \mathrm{kg}$ in Edremit olive oil [Yorulmaz et al. 2013]. In another study, total phenol content of "Bosana" extra virgin olive oil was found between $248-409 \mathrm{mg} / \mathrm{kg}$ oil during 16 months of holding under the light and dark [Del Caro et al. 2006]. Total phenol content of Edremit virgin olive oils were found between $89.2-128.7 \mathrm{mg} / \mathrm{kg}$ harvested in 2005 [Andjelkovic et al. 2009]. This results showed similarity with our results. These differences of total phenol content of virgin olive oils are depending to the variety, climatic conditions, maturity index, irrigation, time and type of harvesting, holding and processing technology [Boskou, 1996].

According to the statistical analyses results, it was determined that the interaction of holding types and holding times affected the changes in total phenol content of Edremit olive oil $(\mathrm{p}<0.001$, Table 3$)$. On the other hand, only holding time was found statistically important on the changes in total phenol content of Uslu olive oil $(\mathrm{p}<0.0001$, Table 4).

\section{Fatty acid composition of olive oil samples}

The major fatty acids found in Edremit and Uslu olive oils had oleic (C18:1), linoleic (C18:2), palmitic (C16:0) and stearic (C18:0) acids. These predominant fatty acids were ranged in all samples between 70.05-71.97\%, 10.22-12.13\%, 12.40-13.87\%, 2.01-2.62 $\%$, respectively. The distribution of fatty acids in the samples was in agreement with the Turkish Food Codex on Olive Oils and Olive Pomace Oils [TFC, 2014/53]. Palmitoleic (C16:1), heptadecanoic (C17:0), heptadecenoic (C17:1), linolenic (C18:3), arachidic (C20:0) and gadoleic (C20:1) acids were determined in low amounts.

In Edremit and Uslu virgin olive oils, total SFA, MUFA and PUFA were almost stable due to the different holding types and times as seen in Table 5 and Table 6 . The samples showed the lowest total PUFA (10.7-12.05 \% for Edremit, 12.16-12.67\% for Uslu) and the highest total MUFA (71.80-73.32\% for Edremit, 71.31-71.99\% for Uslu). As for that total SFA, it varied between 15.77-16.42 \% for Edremit and 15.34-16.26\% for Uslu (Table 5-6). Fluctuations in total SFA, MUFA and PUFA contents observed in olive oil samples are related to holding conditions (Table 5-6). The holding times did not affect their contents in both types. The effect of the intereaction of holding time and type was found statistically important on the changes of total MUFA and PUFA contents of Edremit olive oil ( $\mathrm{p}<0.05$, Table 5), whereas holding time caused significant effect for SFA and PUFA 
contents and also interaction of holding time and type was found important on the changes of total MUFA contents of Uslu olive oil ( $p<0.05$, Table 6).

The fatty acid profiles of our samples were also in good agreement with values obtained for the same varieties in some other studies [Allalout et al. 2009; Yorulmaz et al. 2014]. Some characterization of Turkish olive oils have been investigated by Yorulmaz et al. [2014]. As they reported, average oleic, linoleic, palmitic and stearic acids of Uslu and Edremit olive oils were $72.34-71.57 \%, 10.18-10.37 \%, 12.65-12.98 \%$ and $1.70-2.25 \%$, respectively. the total SFA, MUFA and PUFA contents in different cultivars of Spanish and Greece olive oils have been identified as $14.22-20.18 \%, 61.24-76.61 \%$ and $8.82-13.56 \%$, respectively [Allalout et al.2009]. Total SFA, MUFA and PUFA contents were $15.5 \%$, $73.3 \%$ and $8.6 \%$ in different cultivars [Mendez and Falquй, 2007]. Total SFA, MUFA and PUFA contents of Edremit olive oil were $12.59 \%, 74.29 \%$ and $8.93 \%$. They also indicated the major fatty acid as oleic acid $(72.78 \%)$ in Edremit olive oil [Matthaus and Цzcan, 2011]. The fatty acid composition of olive oil varies widely depending on the cultivar, maturity of the fruit, altitude climate and several other factors [Matthaus and Цzcan, 2011]. Various factors such as harvest period, cultivar and origin affect the formation of the main fatty acids of olive oil in different ways [Bruni et al. 1994].

Table 5

Least squares means of holding times and holding types on total fatty acids composition (Totals SFA, MUFA and PUFA) for Edremit variety olive oil ${ }^{\text {a }}$

\begin{tabular}{|c|c|c|c|}
\hline \multirow{2}{*}{ Source of variation } & \multicolumn{3}{|c|}{ Totals } \\
\cline { 2 - 4 } & $\begin{array}{c}\text { SFA } \\
(\%)\end{array}$ & MUFA (\%) & $\begin{array}{c}\text { PUFA } \\
(\%)\end{array}$ \\
\hline Holding times, week & & & \\
\hline 0 & 16,38 & 71,86 & 11,81 \\
\hline 7 & 15,91 & 72,96 & 11,02 \\
\hline 14 & 16 & 72,07 & 11,88 \\
\hline 21 & 16,1 & 72,19 & 11,62 \\
\hline P-value & 0,18 & 0,0003 & $<0,0001$ \\
\hline Holding types & & & \\
\hline box & 16,15 & 72,41 & 11,43 \\
\hline sack & 16,1 & 72,13 & 11,73 \\
\hline P-value & 0,44 & 0,01 & 0,0005 \\
\hline Holding timesxholding & & & \\
\hline types & & & $11,9 \mathrm{de}$ \\
\hline $0 / \mathrm{b}$ & 16,42 & $71,8 \mathrm{a}$ & $11,72 \mathrm{c}$ \\
\hline $0 / \mathrm{s}$ & 16,34 & $71,92 \mathrm{a}$ & $10,7 \mathrm{a}$ \\
\hline $7 / \mathrm{b}$ & 15,93 & $73,32 \mathrm{~d}$ & $11,33 \mathrm{~b}$ \\
\hline $7 / \mathrm{s}$ & 15,89 & $72,59 \mathrm{c}$ & $1,94 \mathrm{de}$ \\
\hline $14 / \mathrm{b}$ & 15,81 & $72,16 \mathrm{~b}$ & $11,82 \mathrm{~cd}$ \\
\hline $14 / \mathrm{s}$ & 16,2 & $71,97 \mathrm{a}$ & $119 \mathrm{~b}$ \\
\hline $21 / \mathrm{b}$ & 16,43 & $72,34 \mathrm{~b}$ & $11,19 \mathrm{~b}$ \\
\hline $21 / \mathrm{s}$ & 15,77 & $72,04 \mathrm{ab}$ & $12,05 \mathrm{e}$ \\
\hline P-value & 0,07 & 0,05 & 0,0003 \\
\hline
\end{tabular}

Within columns, means with different letters differ $(P<0.05)$.

${ }^{a}$ Letters were not assigned to main effect lsmeans when interaction was significant

SFA: Saturated fatty acids, MUFA: Monounsaturated fatty acids, PUFA: Polyunsaturated fatty acids 
Table 6

Least squares means of holding times and holding types on total fatty acids composition (Totals SFA, MUFA and PUFA) for Uslu variety olive oil ${ }^{a}$

\begin{tabular}{|c|c|c|c|}
\hline \multirow[b]{2}{*}{ Source of variation } & \multicolumn{3}{|c|}{ Totals } \\
\hline & SFA $(\%)$ & $\begin{array}{c}\text { MUFA } \\
(\%)\end{array}$ & $\begin{array}{l}\text { PUFA } \\
(\%)\end{array}$ \\
\hline \multicolumn{4}{|l|}{ Holding times, week } \\
\hline 0 & $15,77 \mathrm{ab}$ & 71,84 & $12,48 \mathrm{ab}$ \\
\hline 7 & $16,21 \mathrm{a}$ & 71,47 & $12,29 b$ \\
\hline 14 & $15,43 b$ & 71,81 & $12,61 \mathrm{a}$ \\
\hline 21 & $15,44 \mathrm{~b}$ & 71,9 & $12,62 \mathrm{a}$ \\
\hline P-value & 0,03 & 0,004 & 0,02 \\
\hline \multicolumn{4}{|l|}{ Holding types } \\
\hline box & 15,69 & 71,8 & 12,55 \\
\hline sack & 15,73 & 71,7 & 12,48 \\
\hline P-value & 0,83 & 0,14 & 0,15 \\
\hline \multicolumn{4}{|l|}{$\begin{array}{l}\text { Stoarge timesxholding } \\
\text { types }\end{array}$} \\
\hline $0 / \mathrm{b}$ & 15,68 & $71,93 \mathrm{~cd}$ & 12,6 \\
\hline $0 / \mathrm{s}$ & 15,86 & $71,75 b c$ & 12,36 \\
\hline $7 / \mathrm{b}$ & 16,26 & $71,31 \mathrm{a}$ & 12,41 \\
\hline $7 / \mathrm{s}$ & 16,15 & $71,62 b$ & 12,16 \\
\hline $14 / b$ & 15,34 & $71,97 \mathrm{~cd}$ & 12,62 \\
\hline $14 / \mathrm{s}$ & 15,51 & $71,64 b$ & 12,6 \\
\hline $21 / b$ & 15,49 & $71,99 \mathrm{~d}$ & 12,57 \\
\hline $21 / \mathrm{s}$ & 15,39 & $71,8 \mathrm{bcd}$ & 12,67 \\
\hline P-value & 0,84 & 0,02 & 0,2 \\
\hline
\end{tabular}

Within columns, means with different letters differ $(P<0.05)$.

${ }^{a}$ Letters were not assigned to main effect lsmeans when interaction was significant

\section{Oxidative Stability of olive oil samples}

The Rancimat method is an accelerated stability test that provides very useful information about the resistance of oil to oxidation [Beltran et al. 2005]. In Figure 3 is given the changes of IP values at $120^{\circ} \mathrm{C}$ for Edremit and Uslu olive oils obtained according to the different holding types and holding times. The initial IP of Edremit and Uslu olive oils were 3.9 and $3.8 \mathrm{~h}$. For Uslu variety, it was observed a decrease during holding period at each holding types until 21 th day. At 21 th day, there was a slight increase from $1.8 \mathrm{~h}$ to $2.1 \mathrm{~h}$ in box and $1.9 \mathrm{~h}$ to $2.7 \mathrm{~h}$ in sack. This caused that nonhomogenous sampling. For Edremit variety, it was not observed a significant decrease during holding period. 


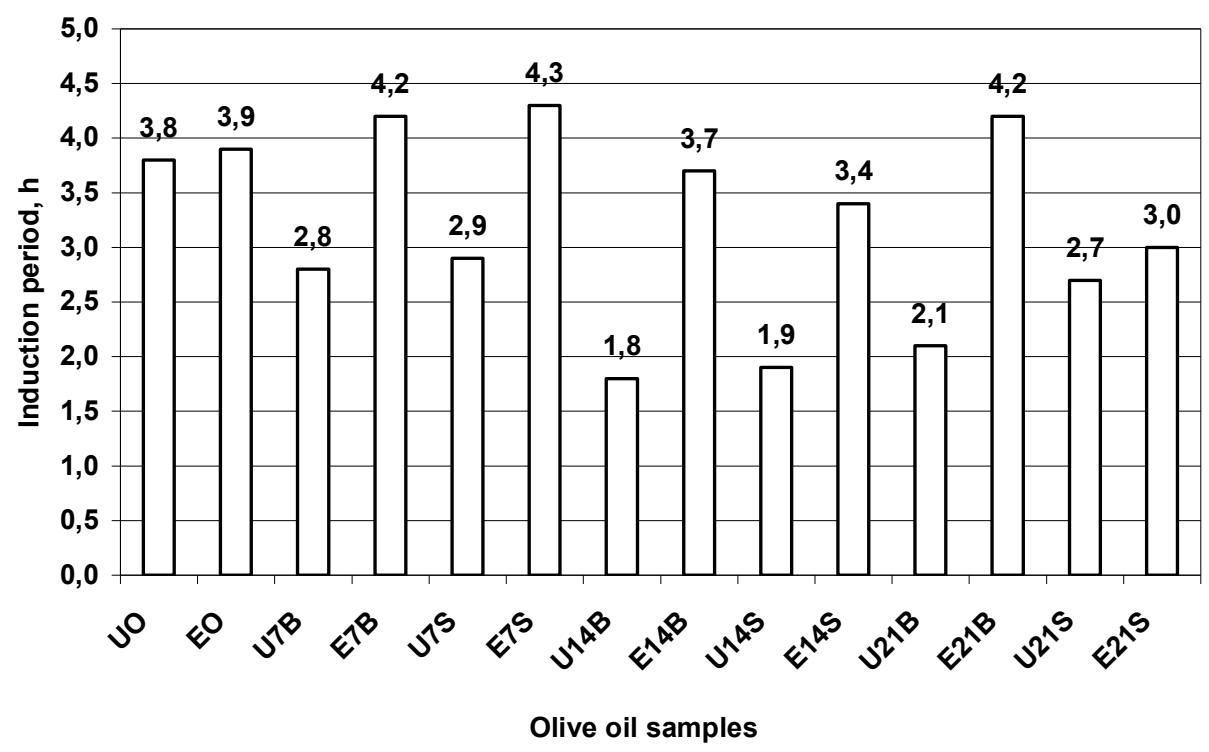

Figure 3. Changes of induction period (hour) of Edremit and Uslu Olive Oil Varieties according to the different storage types and times

UO - Uslu variety first day of harvest

EO - Edremit variety at first day of harvest

U7B - Uslu variety holded at 7 days in box,

E7B - Edremit variety holded at 7 days in box

U7S - Uslu variety holded at 7 days in sack

E7S - Edremit variety holded at 7 days in sack

U14B - Uslu variety holded at 14 days in box

E14B - Edremit variety holded at 14 days in box

U14S - Uslu variety holded at 14 days in sack

E14S - Edremit variety holded at 14 days in sack

U21B - Uslu variety holded at 21 days in box

E21B - Edremit variety holded at 21 days in box

U21S - Uslu variety holded at 21 days in sack

E21S - Edremit variety holded at 21 days in sack

IP of Frantoio cultivar olive oil was determined $3.7 \mathrm{~h}$ at $120^{\circ} \mathrm{C}$ [Mateos et al, 2006]. This finding is similar with our initial IP results. As the ripening occurs, the oil stability decreases according to the results described previously [Gutierrez et al, 1999].

\section{Sensory Profile of olive oil samples}

According to the results of sensory evaluation, two positive attributes of Uslu olive oil as fruitiness and pungency was found higher at 0th day. On the other hand, negative attributes as fusty-humid and winey of Uslu olive oil were found higher at 14th day holding in box (Table 7). All olive oil samples were located at mature index. 
Table 7

Negative and Positive Sensorial Properties of Edremit and Uslu olive oil varieties according to the different holding times and holding types

\begin{tabular}{|c|c|c|c|c|c|c|c|c|}
\hline \multirow{2}{*}{ Variety } & \multirow{2}{*}{$\begin{array}{c}\text { Holding } \\
\text { Times } \\
\text { (week) }\end{array}$} & \multirow{2}{*}{$\begin{array}{c}\text { Holding } \\
\text { Types }\end{array}$} & $\begin{array}{c}\text { Muddy } \\
\text { Sediment }\end{array}$ & Fusty-humid & Winey & $\begin{array}{c}\text { Wet } \\
\text { Wood }\end{array}$ & Rancid & Others \\
\hline Uslu & 0 & - & - & - & - & - & - & - \\
\hline & 7 & box & - & 2 & - & - & 1,9 & - \\
\hline & 14 & box & 0,75 & 2,5 & 3,2 & - & - & - \\
\hline & 21 & box & 3,3 & 2 & - & - & - & - \\
\hline & 7 & sack & - & - & 2,5 & - & - & - \\
\hline & 14 & sack & 3 & - & 1 & - & - & - \\
\hline & 21 & sack & 2,7 & 1,25 & 2,5 & - & - & - \\
\hline Edremit & 0 & - & - & - & - & - & - & - \\
\hline & 7 & box & - & 1,5 & - & - & - & - \\
\hline & 14 & box & - & 2,4 & - & - & - & - \\
\hline & 21 & box & 2 & - & - & - & - & - \\
\hline & 7 & sack & - & - & - & - & - & - \\
\hline & 14 & sack & 2,25 & - & 2 & - & - & - \\
\hline & 21 & sack & - & 2,5 & 3 & - & - & - \\
\hline
\end{tabular}

\begin{tabular}{|c|c|c|c|c|c|c|}
\hline \multirow{2}{*}{ Variety } & \multirow{2}{*}{$\begin{array}{c}\text { Holding } \\
\text { Times } \\
\text { (week) }\end{array}$} & \multirow{2}{*}{$\begin{array}{c}\text { Holding } \\
\text { Types }\end{array}$} & \multicolumn{4}{|c|}{ Positive properties } \\
\hline & & & Fruity & Bitter & Pungent & Maturity \\
\hline \multirow[t]{7}{*}{ Uslu } & 0 & - & 3,5 & 0,5 & 2 & mature \\
\hline & 7 & box & 2,15 & - & 1,3 & mature \\
\hline & 14 & box & 1,5 & - & - & mature \\
\hline & 21 & box & 1,4 & - & - & mature \\
\hline & 7 & sack & 2 & - & 1,3 & mature \\
\hline & 14 & sack & 1,4 & - & 1,6 & mature \\
\hline & 21 & sack & 1,85 & - & - & mature \\
\hline \multirow[t]{7}{*}{ Edremit } & 0 & - & 2,75 & - & 1,5 & mature \\
\hline & 7 & box & 2,45 & - & 1,5 & mature \\
\hline & 14 & box & 2 & 0,5 & - & mature \\
\hline & 21 & box & 2 & - & - & mature \\
\hline & 7 & sack & 3,1 & 1 & 1,5 & mature \\
\hline & 14 & sack & 2 & - & - & mature \\
\hline & 21 & sack & 1,5 & - & - & mature \\
\hline
\end{tabular}

According to the Table 8, while Edremit olive oil at initial day of holding, 7th day in sack and Uslu olive oil at initial day of holding were taken a part of extra virgin olive oil, other samples were classified as virgin olive oil according to the IOOC Method [IOOC, 2010]. Fruity score ranged from 1.4 to 3.5 for both olive oil samples. Fruit score were determined score as from 1.8 to 3.2 in Cornicabra virgin olive oils [Salvador et al. 2000]. Generally, muddy-sediment occurred at the latest holding times as 14th and 21th day for 
both types. One of the negative attributes wet wood was not perceived in any sample (Table 7). Additionally, intensity of rancid was only determined in Uslu olive oil on 7th day of holding at box.

Limits established for Median of defect and fruity attribute (IOC, 2015)

Table 8

\begin{tabular}{|l|c|c|}
\hline & Median of defect & $\begin{array}{c}\text { Median of } \\
\text { the fruity attribute }\end{array}$ \\
\hline Extra virgin olive oil & $\mathrm{Me}=0$ & $\mathrm{Me}>0$ \\
\hline Virgin olive oil & $0<\mathrm{Me} \leq 3.5$ & $\mathrm{Me}>0$ \\
\hline Ordinary virgin olive oil & $3.5<\mathrm{Me} \leq 6.0$ & \\
\hline Lampante virgin olive oil & $\mathrm{Me}>6$ & \\
\hline
\end{tabular}

The sensory caracteristics of bitterness and pungency are due to the activation of taste receptors and trigeminal nerve endings associated with taste buds in fungiform papillae, sensitive to chemical stimuli. In virgin olive oils, these sensations are related to the presence of phenolic compounds and can persist for rather long times after deglutition, showing a clear after-effect that can greatly vary among olive oils in intensity and duration and might affect consumer acceptance [Nieto et al. 2010].

Researches showed that the main reason of quality reduction in the olives which are holded before being processed is the increase in acidity and peroxide number [Cimato, 1990; Garcia et al. 1996].

\section{Conclusion}

The evaluation of the influence of holding types and times of olives on quality parameters and oxidative stability of olive oils is important for exhibit the requirement to not holding olives long time at inconvenient conditions. This study is also of great interest to the local industrial sector and consumers. Quality criteria of olive oils becomes much closer or exceeds the upper legal limits due to negative factors such as harvesting olives at inappropriate maturity index, the long holding period until processing, transport stage after harvesting. In addition to these, producer awareness has also effect on changes of olives quality criteria. Therefore, harvest should be made with appropriate methods and then olives transport to the place of processing and be holded in properly packaged without losing time. At this point, it is not the right approach to say that olive producers has the same consciousness in each region.

Post-harvest transport stage is the stage that showed the most increase the amount of free fatty acidity and oxidation as a result ofthe continued respiration in fruit and hydrolytic degradation.

According to the results, the chemical parameters analysed in the different samples are within the limits established by the legislation, but vary during the holding period and according to the variety. With respect to holding type, the acidification and oxidation of the olive oil increase during holding in sack. When compared two types of olives, Edremit variety has higher quality than Uslu variety in terms of phenolic compounds, peroxide value and thereby oxidative stability. The scores of positive sensorial properties of Edremit variety are higher, as well. 
It is seen that the traditional olives holding methods using generally at villages and towns are not suitable for stability and quality of olive oils obtained from these olives. As a consequence, oxygen and light induce a rapid deterioration in sacks and boxes. Likewise, acidification, loss of phenolic compounds, oxidative rancidity and sensorial quality is favoured. However, olives should be holded at concrete and smooth surfaced panes or under plastic bedstead for not more high than 10-12 cm, after harvesting up to one or two months at maximum. The most important issue for the holding of olive is to provide getting the air and not be crushed.

\section{Acknowledgement}

The authors thank to Scientific Research Projects Coordination Unit of Celal Bayar University, Project No 2013-093, for financial support.

\section{References}

1. Allalout A., Krichene D., Methenni K., Taamalli A., Oueslati I., Daoud D., Zarrouk M. (2009), Characterization of virgin olive oil from Super Intensive Spanish and Greek varieties grown in northern Tunisia, Scientia Horticulturae, 120, pp. 77-83.

2. Anon. (2010), Turkish Standard Animal and vegetable fats and oils, Determination of refractive index, TS 4960 EN ISO 6320.

3. Anon. (2014), Turkish Food Codex of Olive Oil and Olive Pomace Oils Report, Report No: 2014/53.

4. Anwar F., Bhanger M.I., Kazi T.G. (2003), Relationship between Rancimat and Active Oxygen Method values at varying temperatures for several oils and fats, Journal of the American Oil Chemists Society, 80, pp. 151-155.

5. Andjelkovic M., Acun S., Hoed V.V., Verhi R., Camp J.V. (2009), Chemical Composition of Turkish Olive Oil-Ayvalk, Journal of the American Oil Chemists Society, 86, pp. 135-140.

6. AOCS (1993a), Official Methods and recommended practices of the American Oil Chemists Society, 3rd edn, Color Method Cc 13b-45.

7. AOCS (1993b), Official Methods and Recommended practices of the American Oil Chemists Society, Free Fatty Acids Method Ca 5a-40.

8. AOCS (1997), Official Methods and Recommended practices of the American Oil Chemist Society, Preparation of Methyl Esters of Fatty Acids Method Ce 2-66.

9. Baccouri O., Guerfel M., Baccouri B., Cerretani L., Bendini A., Lercker G., Zarrouk M.. ben Miled D.D. (2008), Chemical composition and oxidative stability of Tunisian monovarietal virgin olive oils with regard to fruit ripening, Food Chemistry 109, pp. 743-754.

10. Beltran G., Aguilera M.P., Del Rio C., Sanchez S., Martinez L. (2005), Influence of fruit ripening process on the natural antioxidant content of Hojiblanca virgin olive oils, Food Chemistry, 89, pp. 207-215.

11. Boskou D. (1996), Olive Oil: Chemistry and Technology, In Boskou D (ed), AOCS Press, Champaign, pp. 101-120 
12. Bruni U., Cortesi N., Fiorino P. (1994), Influence of agricultural techniques, cultivar and area of origin on characteristics of virgin olive oil and on levels of some of its minor components, Olivae, 53, pp. 28-41.

13. Cimato A. (1990). Effect of agronomic factors on virgin olive oil quality, Olivae, 31, pp. $20-31$.

14. Del Caro A., Vacca V., Poiana M., Fenu P., Piga A. (2006), Influence of technology, holding and exposure on components of extra virgin olive oil (Bosana cv) from whole and de-stoned fruits, Food Chemistry, 98, pp. 311-316.

15. Garcia J.M., Seller S., Perez-Camıno M.C. (1996), Influence of Fruit Ripennig on Olive Oil Quality, European Journal of Lipid Science and Technology, 144, pp. 3516-3520.

16. Gutfinger T. (1981), Polyphenols in Olive Oils, Journal of the American Oil Chemists Society, 58, pp. 966-968.

17. Gutierrez F., Jimenez B., Ruiz A., Albi M.A. (1999), Effect of olive ripeness on the oxidative stability of virgin olive oil extracted from the varieties Picual and Hojiblanca and on the different components involved, European Journal of Lipid Science and Technology, 47, pp. 121-127.

18. IOC (2015), Trade Standard Applying to Olive Oils and Olive- Pomace Oils, COI/T.15/NC No 3/Rev, 10 November 2015.

19. IOOC (2010), Sensory Analysis of Olive Oil Method for the Organoleptic Assessment of Virgin Olive Oil. IOOC/T.20/Doc. No 15/Rev. 3.

20. IOOC. (2015), World Olive Oil Figures. Statistical Series. Consumption.

21. Kiritsakis A.P. (1998), Olive Oil From The Tree to The Table. Second Edition, pp. 88-93.

22. Mateos R., Uceda M., Aguilera M.P., Escuderos M.E., Maza G. (2006), Relationship of Rancimatmethod values at varying temperatures for virgin olive oils, European Food Research Technology, 223, pp. 246-252.

23. Matthaus B., Ozcan M.M. (2011), Determination of Fatty Acid, Tocopherol, Sterol Contents and 1,2-and 1,3-Diacylglycerols in Four Different Virgin Olive Oil, Journal of Food Processing and Technology, 2(4), pp.1-4.

24. Morello J.R., Motilva M.J., Tovar M.J., Romero M.P. (2004), Changes in commercial virgin olive oil (cv Arbequina) during holding, with special emphasis on the phenolic fraction, Food Chemistry, 85, pp. 357-364.

25. Mendez AI, Falquй E. (2007). Effect of holding time and container type on the quality of extra-virgin olive oil, Food Control. 18,521-529.

26. Nieto L.M., Hodaifa G., Pena J.L.L. (2010), Changes in phenolic compounds and Rancimat stability of olive oils from varieties of olives at different stgaes of ripeness, Journal of the Science of Food and Agriculture, 90, pp. 2393-2398.

27. Psomiadou E., Tsimidou M. (2001), Pigments in Greek virgin olive oils: Occurrence and levels, Journal of the Science of Food and Agriculture, 81, pp. 640-647.

28. SAS. (2000), SAS User's Guide. Cary, NC: SAS Institute, Inc.

29. Salvador M.D., Arand A.F., Alonso S.G., Fregapane G. (2000), Quality characteristics of Cornicabra virgin olive oil, Research on Advanced Oil Chemistry, 1, pp. 31-39.

30. Tanouti K., Elamrani A., Caid H.S., Tahani N. (2011), Quality of Olive Oils Produced in east of Morocco, Electronical Journal of Environmental Agriculture and Food Chemistry, 10(7), pp. 2439-2450. 
31. Vinha A.F., Ferreres F., Silva B.M., Valentao P., Gonçalves A., Pereira J.A., Oliveira M.B., Seabra R.M., Andrade P.B. (2005), Phenolic profiles of Portuguese olive fruits (Olea europaea L.): Influences of cultivar and geographical origin, Food Chemistry, 89(4), pp. 561-568.

32. Yavuz H. (2008), Determination of Some Quality and Genuineness of Turkish Olive Oils. Master thesis, Ankara University Graduate School of Naturel and Applied Sciences Department of Food Engineering.

33. Yorulmaz A., Erinç H., Tekin A. (2013), Changes in Olive and Olive Oil Characteristics During Maturation, Journal of the American Oil Chemists Society, 90, pp. 647-658.

34. Yorulmaz A., Yavuz H., Tekin A. (2014), Characterization of Turkish Olive Oils by Triacylglycerol Structures and Sterol Profiles, Journal of the American Oil Chemists Society, 91, pp. 2077-2090. 